Wiering, B.M., Albada, A., Bensing, J.M., Ausems, M.G.E.M., Dulmen, A.M. van. The influence of dispositional optimism on post-visit anxiety and risk perception accuracy among breast cancer genetic counselees. Psycho-Oncology: 2013, 22(11), 2419-2427

\begin{tabular}{|l|l|}
$\begin{array}{l}\text { Postprint } \\
\text { Version }\end{array}$ & 1.0 \\
\hline Journal website & http://onlinelibrary.wiley.com/doi/10.1002/pon.3292/abstract \\
\hline Pubmed link & $\underline{\text { http://www.ncbi.nlm.nih.gov/pubmed/23630180 }}$ \\
\hline DOI & $10.1002 /$ pon.3292
\end{tabular}

This is a NIVEL certified Post Print, more info at http://www.nivel.eu

\title{
The influence of dispositional optimism on post- visit anxiety and risk perception accuracy among breast cancer genetic counselees
}

\author{
B. M. Wiering ${ }^{1}$, A. AlbAdA ${ }^{1,5}$, J. M. Bensing ${ }^{1,4}$, M. G. E. M. Ausems ${ }^{5}$ AND A. M. VAN \\ DULMEN $^{1,2,3}$
}

${ }^{1}$ NIVEL (Netherlands Institute for Health Services Research), Utrecht, The Netherlands
${ }^{2}$ Department of Primary and Community Care, Radboud University Nijmegen Medical
Centre, Nijmegen, The Netherlands
${ }^{3}$ Department of Health Sciences, Buskerud University College, Drammen, Norway
${ }^{4}$ Department of Health Psychology, Utrecht University, Utrecht, The Netherlands
${ }^{5}$ Department of Medical Genetics, University Medical Center Utrecht, Utrecht, The
Netherlands

\begin{abstract}
Objective:

Much is unknown about the influence of dispositional optimism and affective communication on genetic counselling outcomes. This study investigated the influence of counselees' optimism on the counselees' risk perception accuracy and anxiety, while taking into account the affective communication during the first consultation for breast cancer genetic counselling.

Methods: Counselees completed questionnaires measuring optimism, anxiety and the perceived risk that hereditary breast cancer runs in the family before, and anxiety and perceived risk after the first consultation. Consultations were videotaped. The duration of eye contact was measured, and verbal communication was rated using the Roter Interaction Analysis System.

Results: Less-optimistic counselees were more anxious post-visit ( $\mathrm{b}=-.29 ; \mathrm{p}=$ $.00)$. Counsellors uttered fewer reassuring statements if counselees were more anxious ( $\mathrm{b}=-.84 ; \mathrm{p}=.00$ ) but uttered more reassurance if counselees were less optimistic ( $\mathrm{b}=-.76 ; \mathrm{p}=.01$ ). Counsellors expressed less empathy if counselees perceived their risk as high ( $\mathrm{b}=-1.51 ; \mathrm{p}=.04)$. An increase in the expression of reassurance was related to less post-visit anxiety $(b=-.35 ; p=.03)$. More empathy was related to a greater overestimation of risk $(b=.92 ; \mathrm{p}=.01)$.

Conclusions: Identification of a lack of optimism as a risk factor for high anxiety levels enables the adaptation of affective communication to improve
\end{abstract}


Wiering, B.M., Albada, A., Bensing, J.M., Ausems, M.G.E.M., Dulmen, A.M. van. The influence of dispositional optimism on post-visit anxiety and risk perception accuracy among breast cancer 7 genetic counselees. Psycho-Oncology: 2013, 22(11), 2419-2427

genetic counselling outcomes. Because reassurance was related to less anxiety, beneficial adaptation is attainable by increasing counsellors' reassurance, if possible. Because of a lack of optimally adapted communication in this study, further research is needed to clarify how to increase counsellors' ability to adapt to counselees.

\section{INTRODUCTION}

Breast cancer genetic counselling aims to enable at-risk counselees-either affected by cancer themselves or not - to accurately understand and adaptively cope with genetic risk [1]. It is, however, likely that personality characteristics influence how women cope and adapt to receiving breast cancer risk information. The few studies that included personality characteristics suggest that dispositional optimism-that is, the tendency to believe that one will generally experience good outcomes in life $[2,3]$ - is a predictor of anxiety [4-6]. Dispositional optimism is derived from the behavioural self-regulation theory in which positive expectancies lead to increased effort to attain desired outcomes [7]. This effort is also expected in stressful circumstances.

Research suggests that optimists indeed use an active approach towards coping with stressors or emotions [8]. They are also less likely to experience feelings of helplessness, are more likely to accept the reality of situations $[9,10]$ and cope less emotion-oriented than lessoptimistic individuals [3]. Optimists appear to experience less anxiety because of their way of coping $[3,9,10]$. Anxiety can be a direct emotional response to the consultation and is an important short-term outcome of genetic counselling.

Several studies established an association between low optimism levels and high anxiety in women seeking breast cancer genetic counselling. Research concerning unaffected women from families with a high risk of breast-ovarian cancer found strong associations between low optimism levels and high anxiety levels, depression and cancerspecific distress after the consultation [4]. Optimism also predicted lower anxiety levels at 9-month follow-up [5]. In a study, among recently diagnosed breast cancer patients, low pre-visit optimism levels and quality of life accounted for most of the anxiety, depression and distress after the consultation [6]. Optimism may be important in explaining the individual differences in coping with breast cancer risk information.

Apart from anxiety, an important outcome of breast cancer genetic counselling is the accuracy of risk perception, that is, counselees' interpretation of the risk that hereditary breast cancer runs in their family compared with the estimates as given by the counsellor [11]. Accurate risk perception is regarded as a central concept that measures the efficiency of genetic counselling and is positively associated with adherence to mammography screening [12]. Although some studies found that counselees underestimate their risk $[13,14]$, most counselees perceive their risk as higher after the consultation than the counsellor's estimation [15-17]. Given that optimists have a tendency to have positive expectancies, it can be expected that optimistic counselees estimate their risk lower than the average counselees. A lower estimation compared with the overestimation of others is likely to be more accurate. Whereas some research investigated the influence of optimism on anxiety, little research focused on the influence of optimism on the accuracy of risk perception. 
Wiering, B.M., Albada, A., Bensing, J.M., Ausems, M.G.E.M., Dulmen, A.M. van. The influence of dispositional optimism on post-visit anxiety and risk perception accuracy among breast cancer 7 genetic counselees. Psycho-Oncology: 2013, 22(11), 2419-2427

Although some studies concerning health risks find that optimists are more likely to underestimate their risk [18], this was not found in all studies concerning breast cancer risk. In a communitybased study, optimists were less likely to overestimate their risk of breast cancer [19]. However, in another study, no relation between the accuracy of risk perception and optimism was found after genetic counselling [17]. Apart fromthe lack of research investigating the influence of optimism on genetic counselling outcomes, no studies take into account the mediating influence of affective communication.

Pieterse et al. [20] found that receiving more psychosocial information and longer counsellor eye contact during the first cancer genetic counselling consultation were related to higher anxiety levels. Lobb et al. [21] showed that women whose counsellors used more supportive communication during the first consultation experienced more anxiety about breast cancer at 4 weeks of follow-up. Apparently, the outcome of genetic counselling is mediated by affective communication but in what way is not clear. This study therefore firstly aims to investigate the influence of optimism on post-visit risk perception accuracy and anxiety. Secondly, this study investigates whether counsellors varied their affective communication according to counselees' baseline anxiety, optimism and risk perception, that is, whether counsellors used more affective communication if counselees were more anxious, less optimistic or perceived their risk as high, but without taking into account the counselees' wishes.

Thirdly, this study aims to investigate how affective communication mediates the relationship between optimism and post-visit anxiety and risk perception accuracy. Expected is that counsellors will express more empathy and reassurance and that the counselees will express more concerns if they are anxious, less optimistic or have a high risk perception, which might improve genetic counselling outcomes. Results will provide insight into the influence of optimism on genetic counselling outcomes and whether counsellors varied their communication to the counselees and reached desired genetic counselling outcomes.

\section{METHOD}

\section{Participants}

Counselees were recruited from the Department of Medical Genetics of the University Medical Center Utrecht (UMCU). This department offers breast cancer genetic counselling according to the Dutch guidelines [22]. The department included consecutive new counselees from February 2008 to April 2010. Adult counselees who were the first of their first-degree family members to seek breast cancer genetic counselling were sent study information and an opt-out form with their appointment letter.

Counselees were ineligible when they requested DNA testing because of an identified BRCA1/2 gene mutation in a relative or when they lacked Internet or email access.

\section{Procedure}

The study is approved by the medical ethical committee of UMCU and is registered in the Dutch Trial Register (ISRCTN82643064). Genetic counselling usually consists of one or two consultations. This study focuses on the first consultation. Counselees completed online questionnaires within 1 week before and approximately 1 week 
Wiering, B.M., Albada, A., Bensing, J.M., Ausems, M.G.E.M., Dulmen, A.M. van. The influence of dispositional optimism on post-visit anxiety and risk perception accuracy among breast cancer 7 genetic counselees. Psycho-Oncology: 2013, 22(11), 2419-2427

after the consultation. They received a personal questionnaire login by mail, an email 1 week before and a telephone reminder 2 days before the consultation. At the start of the consultation, the counsellor collected the informed consent forms. The consultations were videotaped using an unmanned camera directed at the counsellor. Each counsellor completed a questionnaire after the consultation. Data were gathered for a randomized controlled trial of the effects of a pre-visit-tailored website on genetic counselling outcomes $[23,24]$. The participants were randomized to receive usual care or usual care plus an educational website. In the present study, this group allocation will be controlled for.

\section{Measures}

Counselee's birth year, education level, personal and family cancer history, marital status and whether the counselee had children were assessed with the baseline questionnaire. Counselee's birth year and personal and family cancer history were checked with the medical files.

\section{QUESTIONNAIRES}

Indication for DNA testing was assessed with a question answered by the counsellor after the consultation: 'Is there an indication for DNA-testing'? Perceived risk was assessed before and after the consultation.

Counselees were asked, 'What is, according to you, the risk that the breast cancer in your family is hereditary?' Counselees rated their perceived risk on a numerical visual analogue scale from $0 \%$ to $100 \%$. The counsellors answered a similar scale after the consultation [25]. Risk perception accuracy was defined as the difference between the counselee's risk perception and the counsellor's risk estimation.

Generalized state anxiety was measured before and after the consultation with the Dutch-shortened 10-item version of the State-Trait Anxiety Inventory [26]. The statements assess how respondents currently feel on a 4-point scale ('not at all'-'very much'). Internal consistencies were high before $(\mathrm{a}=.92)$ and after $(\mathrm{a}=.95)$ the consultation.

The State-Trait Anxiety Inventory has been reliably used in cancer genetic counselling studies before [25].

Optimism was assessed before the consultation using the Life Orientation Test. This eight-item subscale of the Self-Assessment Questionnaire-Nijmegen [27] measures optimism with a four-point scale ('almost never'-'nearly always'). The internal consistency for the scale was high $(\mathrm{a}=.88)$.

\section{CODING INSTRUMENTS}

Communicative behaviours were measured by coding the duration of counsellor's counselee-directed eye gaze and by coding verbal communication with the use of RIASgene, an adapted version of the Roter Interaction Analysis System (RIAS). This observation system is used for coding physician and patient communication [28]. The system distinguishes mutually exclusive and exhaustive coding categories into which verbal utterances that convey a complete thought can be classified. A distinction is made between affective or socio-emotional categories and instrumental or task-oriented categories. The adaptation consisted of an elaboration of categories [29]. Coding was conducted with Observer XT7 software [30]. This study focused on the affective categories of the RIAS. 
Wiering, B.M., Albada, A., Bensing, J.M., Ausems, M.G.E.M., Dulmen, A.M. van. The influence of dispositional optimism on post-visit anxiety and risk perception accuracy among breast cancer 7 genetic counselees. Psycho-Oncology: 2013, 22(11), 2419-2427

Affective communication includes those exchanges with explicit socio-emotional content, meant to build social and emotional rapport, such as empathy, concern or reassurance [28]. Furthermore, patient-directed eye gaze was found to be an important form of nonverbal affective communication [31]. This study therefore included the following four affective communicative behaviours.

Firstly, counsellor's reassurance was coded if the counsellor reassured, encouraged or showed optimism. Secondly, counsellor's empathy was coded if the counsellor made utterances concerning empathy, partnerships and legitimization.

Thirdly, counselee's concerns were coded if the counselee made a statement in which he or she gave information about his or her worries. Fourth, counsellor's eye gaze was coded by timing the time that the counsellor looked in the counselee's direction. Coding was conducted by three trained coders. Inter-rater reliability was calculated on a random $10 \%$ of the consultations observed by the main coder $(\mathrm{N}=75)$. Reliability coefficients (intra-class correlation) were high, counselee categories averaged .92 (range .85-.99) and counsellor categories averaged .93 (range .87-.98). Inter-rater reliability of counsellor's eye gaze was .99. Intra-coder reliability was calculated on the main coder's recording of a random $10 \%$ of his or her consultations. Intra-coder reliability coefficients averaged .86 (range .62-.99) for counselee categories and .87 (range .58-.99) for counsellor categories. Intra-coder reliability of counsellor's eye gaze was .99 .

\section{Statistical analysis}

In accordance with Street [32], the absolute frequencies of utterances were analysed because medical consultations are communicative constructions and the length of the consultation reflects the interactants' communicative choices.

The frequencies of counselee and counsellor utterances were calculated. If two or more counsellors and/or counselees were present, their utterances were added. Participating counselees and decliners were compared on sociodemographics and cancer history using Chi-square tests and t-tests. Post-visit, out of the counselees who completed the baseline questionnaire, 18 counselees did not complete the anxiety questionnaire, and 12 counselees did not complete the risk perception questionnaire. No significant differences between counselees who only completed the anxiety baseline questionnaire and counselees who completed the baseline and post-visit questionnaires were found.

Linear regressions were used to select covariates for the multilevel structure of measurements. Multilevel regression analyses with random intercepts were conducted.

Multilevel analysis takes into account that consultations are not independent from each other but are nested within counsellors. The consultations were the first level of analyses, and the counsellors were the second. Multilevel analysis thereby corrects for the number of consultations per counsellor. The percentage of variance at the counsellor level (intra-class correlation) for anxiety and accuracy of risk perception was low (3\% and $15 \%$, respectively).

The fit of the models was checked by comparing the Akaike information criterion (Table 2). Analyses were controlled for baseline values, disease status, indication for DNA testing and randomized controlled trial group allocation. For analyses concerning anxiety, the counsellor's risk estimation was also controlled for. Empathy, reassurance and concern statements were each categorized into three categories with dummy variables. The categorizations were based on earlier research 
Wiering, B.M., Albada, A., Bensing, J.M., Ausems, M.G.E.M., Dulmen, A.M. van. The influence of dispositional optimism on post-visit anxiety and risk perception accuracy among breast cancer 7 genetic counselees. Psycho-Oncology: 2013, 22(11), 2419-2427

suggesting that statements of empathy represent critical incidents of affective bonding, and even modest differences in the use of these statements represent clinically relevant distinctions in communication [33]. One expression of empathy might even be more important than the rest of the consultation [34]. The communication was therefore categorized as follows: the behaviour did not take place $(=0)$, the behaviour took place once $(=1)$ and the behaviour took place more than once $(>1)$. By using these categorizations, modest differences might be detectable.

The statements and counsellors' eye gaze were controlled for. Logistic regressions were conducted to analyse the variation of counsellors' affective communication according to counselees' baseline anxiety and optimism levels and risk perception. For these analyses, the communication variables were changed into dummy variables indicating whether a communicative behaviour had taken place $(=1)$ or not $(=0)$. Two-sided tests of significance were performed, and results were considered statistically significant when $\mathrm{p}<.05$. Analyses were conducted using Stata 11 [35].

\section{RESULTS}

\section{Response}

Twenty-four counselees were ineligible because of a lack of Internet or email access (24 of 371; 6.5\%). During 27 months, 336 eligible counselees received study information, and 197 were willing to participate. The response rate was 58.6\%. Almost half of the decliners gave a reason (43.9\%). Most preferred the visit not to be videotaped (65.7\%). There were no significant differences between participants and decliners in age $(\mathrm{t}=1.62 ; \mathrm{p}=.11)$, disease status $\left(\mathrm{w}_{2}=.05\right.$; d.f. $\left.=1 ; \mathrm{p}=.81\right)$, family history of cancer $\left(\mathrm{w}_{2}=.06\right.$; d.f. $\left.=1 ; \mathrm{p}=.82\right)$ and referral pathway $\left(\mathrm{w}_{2}=.87\right.$; d.f. $=1$; $\mathrm{p}=.35$ ). Five consultations were not videotaped because of technical or logistic failure (Figure 1).

\section{Counselees' characteristics}

As shown in Table 1, most counselees had a partner (86.3\%) and one or more children (68.4\%). Counselees were on average highly educated, with $41.1 \%$ of the counselees completing university (MSc/BSc) or higher vocational education (BSc). Of the 190 counselees, $40.0 \%$ were affected by breast cancer. One counselee was affected by ovarian cancer. More than half of the counselees (53.2\%) were unaffected but were closely related to someone who was affected. The majority of the counselees were referred to genetic counselling by their GPs (48.7\%). Of the 190 counselees, 144 (75.8\%) received an indication for DNA testing (either for the counselee or for an affected relative). Counsellors estimated that most counselees (70\%) had a higher than $10 \%$ chance that hereditary breast cancer runs in their family, which is the cutoff point for an indication for DNA testing.

\section{Counsellors}

All 14 genetic counsellors providing breast cancer genetic counselling at the Department of Medical Genetics participated and recorded 4-29 consultations each. Six were genetic counsellors; three of whom were in training (all women). Three were clinical geneticists (two men and one woman), and five were clinical geneticists in training (all women). Counsellors were aged 26-53 years $(M=36.22$; standard deviation $=9.60)$. 
Wiering, B.M., Albada, A., Bensing, J.M., Ausems, M.G.E.M., Dulmen, A.M. van. The influence of dispositional optimism on post-visit anxiety and risk perception accuracy among breast cancer 7 genetic counselees. Psycho-Oncology: 2013, 22(11), 2419-2427

Optimism, baseline anxiety and baseline risk perception Counselees’ optimism levels were associated with counselees' baseline anxiety $(\mathrm{r}=-.55$; $\mathrm{p}=.00)$ but not with counselees' baseline risk perception $(r=-.12 ; \mathrm{p}=.14)$.

Optimism, post-visit anxiety and the accuracy of risk perception As shown in Table 2, lower optimism levels were associated with higher post-visit anxiety levels when controlled for baseline anxiety ( $\mathrm{b}=-.29 ; \mathrm{p}=.00$ ). Optimism was not significantly associated with the accuracy of post-visit risk perception $(\mathrm{b}=-.04 ; \mathrm{p}=.56)$.

Counselees who received an indication for DNA testing had a less accurate risk perception post-visit $(\mathrm{b}=.40 ; \mathrm{p}=.01)$.

Affective communication, anxiety and (the accuracy of) risk perception In Table 3, the categorization of affective communication is shown. As shown in Table 4, higher levels of counselees' baseline anxiety led to the expression of less reassurance by the counsellor $(\mathrm{b}=-.84 ; \mathrm{p}=.00)$. Counsellors expressed more reassurance if counselees were less optimistic $(\mathrm{b}=-.76 ; \mathrm{p}=.01)$. Less empathy was expressed if counselees perceived their risk as high pre-visit $(b=-1.51 ; \mathrm{p}=.04)$.

As shown in Table 2, more expression of reassurance by the counsellor was related to less post-visit anxiety ( $b=-.35 ; p=.03$ ). An increase in the expression of empathy was related to a greater overestimation and therefore less accurate risk perception post-visit $(\mathrm{b}=.92 ; \mathrm{p}=.01)$.

\section{DisCUSSION}

This study was to our knowledge the first to investigate the influence of dispositional optimism on anxiety and the accuracy of risk perception, while taking into account the affective communication that took place during the first consultation for breast cancer genetic counselling. The present study found that higher optimism levels were associated with lower post-visit anxiety levels. This is in accordance with our expectations based on earlier research suggesting that optimism-that is, positive outcome expectancies - shields against anxiety [4-6], even in uncontrollable, serious situations [3]. Research of the mechanisms behind this relationship suggests that, compared with less-optimistic individuals, optimists are more likely to use approach coping [figure 1] strategies [8] and less likely to use emotion-orientated coping strategies [3]. The difference in coping strategies might be why optimists experience less anxiety $[3,9,10]$.

Not only was optimism expected to influence anxiety, counsellors were also expected to vary their affective communication according to counselees' baseline anxiety and optimism levels. Furthermore, affective communication was expected to mediate the effect of optimism on anxiety. Although counsellors expressed more reassurance if a counselee was less optimistic, counsellors expressed fewer reassurances while communicating with a more anxious counselee. Nonetheless, reassurance was found to mediate the influence of optimism on post-visit anxiety. More counsellor reassurance was associated with a decrease in post-visit anxiety. The number of times empathy was expressed did not influence counselees' post-visit levels of anxiety. This finding that empathic statements failed to influence anxiety is in line with earlier research suggesting that empathy influences depressive symptoms but not anxiety [36].

A previous study by Lobb et al. [21] found that addressing emotional concerns by using more supportive communication, for example, discussing feelings and 
Wiering, B.M., Albada, A., Bensing, J.M., Ausems, M.G.E.M., Dulmen, A.M. van. The influence of dispositional optimism on post-visit anxiety and risk perception accuracy among breast cancer 7 genetic counselees. Psycho-Oncology: 2013, 22(11), 2419-2427

concerns, increased anxiety, whereas the current study suggests that empathic statements can be given without increasing anxiety.

\section{[TABLE 1]}

Alongside the influence of optimism on anxiety, it was also expected that higher optimism levels would lead to a more accurate risk perception. This study did not find an influence of optimism on the accuracy of risk perception.

This is in accordance with earlier research [17]. Other factors such as personal loss [37] and identification with affected family members [38] may be more important for the accuracy of risk perception.

Counsellors' affective communication was expected to mediate the relationship between optimism and the accuracy of risk perception. It was also expected that counsellors would adjust their affective communication to counselees' baseline risk perception. However, the expression of reassurance did not vary depending on counselees' baseline risk perception, nor did it influence the postvisit accuracy of risk perception. Furthermore, counsellors expressed less empathy if counselees perceived their risk as high. However, this might be positive, because an increase in empathy was related to a greater overestimation of risk. Counselees with a high perceived risk might have overestimated their risk even more if counsellors would have expressed more empathy.

Not only counsellors but also counselees were expected to vary their communication according to their baseline levels. No variation in counselees' communication was found. However, it must be noted that only concerns were taken into account. Counselees might have communicated their baseline levels by using other communicative behaviours. In a study by Bensing et al. [39], patients expressed their high anxiety levels mostly through nonverbal communication.

Not only verbal communication but also counsellors' eye gaze was expected to influence anxiety levels because Pieterse et al. [20] found that longer counsellor eye contact was related to higher post-visit anxiety levels. In the present study, no association with anxiety was found. The lack of influence of eye gaze on counselees' post-visit anxiety might be influenced by limited power. Further research may give more insight into the relationship between counsellors' eye gaze and counselee outcomes.

Concluding, optimism was related to anxiety, an important short-term outcome of genetic counselling. Although optimism might not improve risk perception accuracy, it apparently influences how counselees cope with their risk.

Whereas most affective communication had no influence, counsellors' reassurance influenced post-visit anxiety positively, and empathy influenced the accuracy of postvisit risk perception negatively. The lack of a beneficial influence of most affective communication might be due to nonoptimal counsellor communication. Counsellors did not seem to adapt their affective communication effectively to counselees' anxiety levels and risk perceptions.

Although counsellors varied some of their affective communication to baseline anxiety and optimism levels and risk perception, it was mostly in contrast with what was expected. It must be noted that adaptation of communication according to baseline anxiety, optimism and risk perception might be difficult, because counselees did not seem to communicate these. The structured nature of the first visit [29] and the lack of communication training genetic counsellors receive may also have 
Wiering, B.M., Albada, A., Bensing, J.M., Ausems, M.G.E.M., Dulmen, A.M. van. The influence of dispositional optimism on post-visit anxiety and risk perception accuracy among breast cancer 7 genetic counselees. Psycho-Oncology: 2013, 22(11), 2419-2427

prevented the adaptation of affective communication. The lack of affective communication that is successfully adapted to counselees' baseline anxiety levels and risk perception is not unusual. Lobb et al. [40] found that patient demographics were more likely to predict counsellors' communication than the counselees' psychological status. Unsurprisingly, this resulted in a lack of beneficial influence of most affective communication on genetic counselling outcomes.

The present conclusions are made with some caution because of study limitations. The response rate is moderate, but it is relatively high for studies using video recordings of genetic counselling visits [25]. Most importantly, there were no significant differences between responders and decliners. The high percentage of missing values on counselees' risk perception was due to a technical error in the Web-based questionnaire and is therefore unlikely to be related to counselees' characteristics.

[TABLE 2] [TABLE 3]

Consistent with earlier findings of the UMCU [29] and other Dutch genetics centres $[41,42]$, almost half of the counselees have higher education (MSc/BSc). The results are therefore representative for breast cancer genetic counselling counselees. The results in this study might be influenced by limited power. Limited power may be caused by the number of covariates necessary for the analyses and the limited number of participants and possibly also because only 14 counsellors participated. Although more counsellors are recommended for multilevel analyses, multilevel analyses were still relevant because of the nesting of counselees within counsellors. Only the first visit was used for this study. Most counselees continued to have a second consultation during which the DNA test results are disclosed and a risk estimation is given.

\section{[TABLE 4]}

Not all first consultations (80\%) included a risk estimation [24]. Furthermore, it must be noted that this study did not focus on whether counselees recalled their risk factually accurate but on how they perceived their risk [43].

Anxiety and risk perception were analysed as independent genetic counselling outcomes, although they may influence each other. It must be noted that with RIAS, utterances are not coded for its quality; that is, it was not coded whether reassurance was appropriate to reassure counselees concerning their hereditary risk. No distinction can therefore be made between true and false reassurances [44]. Furthermore, communication was measured in frequencies, whereas sequential analyses might give a better indication of the appropriateness of timing of the utterance. Although communication is a dynamic, interactive process whereby counsellors and counselees facilitate each other's communication [45,46], no communication sequences were taken into account. Further research is necessary to investigate the influence of communication patterns on genetic counselling outcomes.

An important strength of the present study is the combination of video-recorded consultations and questionnaires.

Results of the questionnaires were linked to communication, which provided a unique insight into communication and its associations with genetic counselling outcomes. 
Wiering, B.M., Albada, A., Bensing, J.M., Ausems, M.G.E.M., Dulmen, A.M. van. The influence of dispositional optimism on post-visit anxiety and risk perception accuracy among breast cancer 7 genetic counselees. Psycho-Oncology: 2013, 22(11), 2419-2427

The findings of this study have important implications for genetic counselling practice and research. The identification of a lack of optimism as a possible risk factor for high anxiety levels following the first genetic counselling consultation suggests the possibility to identify counselees’ optimism levels during the intake. Furthermore, because more reassurance was related to a decrease in anxiety levels, counsellors can adapt their affective communication by increasing their expression of reassurance to improve genetic counselling outcomes.

This development of more counselee-focused cancer genetic counselling requires the ability of counsellors to adapt to their counselees. The present study found that in the first visit for breast cancer, genetic counselling affective communication was not optimally adapted to counselees' baseline anxiety and risk perception. A partial explanation for this finding might be that it is difficult to adapt communication if counselees do not express their anxiety or risk perception. Other suggestions may be that the structured nature of the visit [29] leaves little room for adaptation and that counsellors are fairly untrained in communication, which might make adaptation even more difficult. It is therefore important for counsellors to ask whether counselees are anxious and whether they think they are at high risk. In addition, more communication training can improve the use of affective communication [47] and should be introduced into the training of a genetic counsellor. Furthermore, research is necessary to find ways to increase counsellors' ability to adapt to their counselees.

\section{Conflict of interest}

The authors have stated that there is none.

\section{REFERENCES}

1. Smerecnik CMR, Mesters I, Verweij E, De Vries NK, De Vries H. A systematic review of the impact of genetic counseling on risk perception accuracy. J Genet Couns 2009;18:217228.

2. Carver CS, Scheier MF. Optimism, coping, and health: assessment and implications of generalized outcome expectancies. Health Psychol 1985;4:219-247.

3. Fournier M, De Ridder D, Bensing J. How optimism contributes to the adaptation of chronic illness. A prospective study into the enduring effects of optimism on adaptation moderated by the controllability of chronic illness. Pers Indiv Differ 2002;33:1163-1183.

4. Geirdal A-, Dahl AA. The relationship between psychological distress and personality in women from families with familial breast/ ovarian or hereditary non-polyposis colorectal cancer in the absence of demonstrated mutations.

J Genet Couns 2008; 17: 384-393.

5. Norman P, Brain K. Does dispositional optimism predict psychological responses to counselling for familial breast cancer. J Psychosom Res 2007; 63: 247-254.

6. Schlich-Bakker KJ, Wárlám-Rodenhuis CC, Van Echtelt J, Van den Bout J, Ausems MGEM, Ten Kroode HFJ. Short term psychological distress in patients actively approached for genetic counselling after diagnosis of breast cancer. Eur J Cancer 2006;42:2722-2728.

7. Carver CS, Scheier MF. On the Self-Regulation of Behavior. Cambridge University Press: New York, 1998.

8. Nes LS, Segerstrom SC. Dispositional optimism and coping: a meta-analytic review. Pers Soc Psychol Rev 2006;10:235-251.

9. Carver CS, Pozo C, Harris SD, et al. How coping mediates the effect of optimism on distress: a study of women with early stage breast cancer. J Pers Soc Psychol 1993;65:375-390.

10. Carver CS, Scheier MF, Segerstrom SC. Optimism.

Clin Psychol Rev 2010;30:879-889. 
Wiering, B.M., Albada, A., Bensing, J.M., Ausems, M.G.E.M., Dulmen, A.M. van. The influence of dispositional optimism on post-visit anxiety and risk perception accuracy among breast cancer genetic counselees. Psycho-Oncology: 2013, 22(11), 2419-2427

11. Pieterse AH, Ausems MG, Spreeuwenberg $P$, van Dulmen S. Longer-term influence of breast cancer genetic counseling on cognitions and distress: smaller benefits for affected versus unaffected women. Patient Educ Couns 2011;85:425-431.

12. Katapodi MC, Lee KA, Facione NC, Dodd MJ. Predictors of perceived breast cancer risk and the relation between perceived risk and breast cancer screening: a meta-analytic review. Prev Med 2004;38:388-402.

13. Evans DGR, Blair V, Greenhalgh R, Hopwood P, Howell A. The impact of genetic counselling on risk perception in women with a family history of breast cancer. $\mathrm{Br} \mathrm{J}$ Cancer 1994;70:934-938.

14. Cull A, Anderson EDC, Campbell S, Mackay J, Smyth E, Steel M. The impact of genetic counselling about breast cancer risk on women's risk perceptions and levels of distress. $\mathrm{Br}$ J Cancer 1999;79:501-508.

15. LloydS, WatsonM, et al. Familial breast cancer: a controlled study of risk perception, psychological morbidity and health beliefs in women attending for genetic counselling. $\mathrm{Br} \mathrm{J}$ Cancer 1996;74:482-487.

16. Watson M, Lloyd S, Davidson J, et al. The impact of genetic counselling on risk perception andmental health in womenwith a family history of breast cancer. $\mathrm{Br} \mathrm{J}$ Cancer 1999;79:868-874.

17. Gurmankin AD, Domchek S, Stopfer J, Fels C, Armstrong K. Patients' resistance to risk information in genetic counseling for BRCA1/2.

Arch Intern Med 2005;165:523-529.

18. Van der Weijden T, Van Steenkiste B, Stoffers HEJH, Timmermans DRM, Grol R.

Primary prevention of cardiovascular diseases in general practice: mismatch between cardiovascular risk and patients' risk perceptions.

Med Decis Making 2007;27:754-761.

19. McGregor AM, Bowen DJ, Ankerst DP, Andersen MR, Yasui Y, McTiernan A. Optimism, perceived risk of breast cancer, and cancer worry among a community-based sample of women. Health Psychol 2004;23:339-344.

20. Pieterse AH, Van Dulmen AM, Beemer FA, Bensing JM, Ausems MGEM. Cancer genetic counseling: communication and counselees' post-visit satisfaction, cognitions, anxiety, and needs fulfilment. J Genet Counsel 2007;16:85-96.

21. Lobb EA, Butow PN, Barratt $A$, et al. Communication and information-giving in high-risk breast cancer consultations: influence on patient outcomes. Br J Cancer 2004;90:321-327.

22. STOET, Association Clinical Genetics Netherlands, Working group Clinical Oncogenetics: Hereditary tumours: guidelines for diagnostics and prevention. [Erfelijke tumoren: Richtlijnen voor diagnostiek en preventie]. www.stoet.nl. 2010.

23. Albada A, van Dulmen S, Otten R, Bensing JM, Ausems MGEM. The development of Einfo geneca: a computer-tailored intervention prior to breast cancer genetic counselling.

J Genet Couns 2009;18:326-338.

24. Albada A, Van Dulmen S, Lindhout D, Bensing JM, Ausems MGEM. A pre-visit tailored website enhances counselees' realistic expectations and knowledge and fulfils information needs for breast cancer genetic counselling. Fam Cancer 2012;11:85-95.

25. Pieterse AH, Ausems MGEM, Van Dulmen AM, Beemer FA, Bensing JM. Initial cancer genetic counseling consultation: change in counselees' cognitions and anxiety, and association with addressing their needs and preferences. Am J Med Genet 2005;137:2735.

26. Van der Ploeg HM, Defares PB, Spielberger CD. Handleiding bij de Zelfbeoordelings Vragenlijst (ZBV) [Manual of the Dutch version of the State Trait Anxiety Inventory].

Swets and Zeitlinger: Lisse, 1980.

27. Bleiker EM, van der Ploeg HM, Hendriks JH, Ader HJ. Personality factors and breast cancer development: a prospective longitudinal study. J Natl Cancer Inst 1996;88:14781482.

28. Roter DL, Larson SM. The Roter Interaction Analysis System (RIAS): utility and flexibility for analysis of medical interactions. Patient Educ Couns 2002;46:243-251.

29. Pieterse AH, Van Dulmen AM, Ausems MGEM, Beemer FA, Bensing JM.

Communication in cancer genetic counselling: does it reflect counselees' pre-visit needs and preferences? Br J Cancer 2005;92:1671-1678. 
Wiering, B.M., Albada, A., Bensing, J.M., Ausems, M.G.E.M., Dulmen, A.M. van. The influence of dispositional optimism on post-visit anxiety and risk perception accuracy among breast cancer genetic counselees. Psycho-Oncology: 2013, 22(11), 2419-2427

30. Noldus L, Trienes R, Hendriksen A, Jansen H, Jansen R. The Observer Video-Pro: new software for the collection, management, and presentation of time-structured data from videotapes and digital media files. Behav Res Methods Instrum Comput 2000;32:197-206. 31. Caris-Verhallen WMCM, Kerkstra A, Bensing JM. Non-verbal behaviour in nurse-elderly patient communication. J Adv Nurs 1999;29:808-818.

32. Street RL. Analyzing communication in medical consultations. Do behavioural measures correspond to patients' perceptions? Med Care 1992;30:976-988.

33. Paasche-Orlow $M$, Roter $D$. The communication patterns of internal medicine and family practice physicians. J Am Board Fam Med 2003;16:485-493.

34. Levinson W, Hauser J. More than meets the ear. Med Care 1998;36:1437-1438.

35. StataCorp. 2009. Stata Statistical Software: Release 11. StataCorp LP: College Station, TX.

36. Duric $\mathrm{V}$, Butow $\mathrm{P}$, Sharpe $\mathrm{L}$, et al. Reducing psychological distress in a genetic counseling consultation for breast cancer. J Genet Couns 2003;12:243-264.

37. Rothman AJ, Kiviniemi MT. Treating people with information: an analysis and review of approaches to communicating health risk information. J Natl Cancer Inst Monogr 1999;25:44-51.

38. Fallowfield L. Psychosocial aspects of risk appraisal. Breast Cancer Res 2008;10 (Suppl 4): S14.

39. Bensing JM, Verheul W, Van Dulmen AM.

Patient anxiety in the medical encounter: a study of verbal and nonverbal communication in the general practice. Health Educ 2008; 108: 373-383.

40. Lobb EA, Butow PN, Meiser B, et al.

Tailoring communication in consultation with women from high risk breast cancer families.

Br J Cancer 2002;87:502-508.

41. Van Asperen CJ, Van Dijk S, Zoeteweij MW, et al. What do women really want to know? Motives for attending familial breast cancer clinics. J Med Genet 2002;39:410-414.

42. Van Dijk S, Timmermans DRM, Meijers- Heijboer H, Tibben A, Van Asperen CJ, Otten W. Clinical characteristics affect the impact of an uninformative DNA test result: the course of worry and distress experienced by women who apply for genetic testing for breast cancer. J Clin Oncol 2006; 24:3672-3677.

43. Vos J, Oosterwijk JC, Gómez-García E, et al.

Perceiving cancer-risks and hereditylikelihood in genetic-counseling: how counselees recall and interpret BRCA 1/2-test results. Clin Genet 2011;79:207-218.

44. Dijk S, Otten W, Timmermans DRM, et al.

What's the message? Interpretation of an uninformative BRCA1/2 test result for women at risk of familial breast cancer. Genet Med 2005;7:239-245.

45. Bensing JM, Verheul W, Jansen J, Langewitz WA. Looking for trouble: the added value of sequence analysis in finding evidence for the role of physicians in patients' disclosure of cues and concerns. Med Care 2010;48:583-588.

46. Bensing JM, Schreurs K, De Rijk A. The role of general practitioner's affective behaviour in medical encounters. Psychol Health 1996;11:825-838.

47. Bonvicini KA, Perlin MJ, Bylund CL, Carrol G, Rouse RA, Goldstein MG. Impact of communication training on physician expression of empathy in patient encounters. Patient Educ Couns 2009;75:3-10. 
Wiering, B.M., Albada, A., Bensing, J.M., Ausems, M.G.E.M., Dulmen, A.M. van. The influence of dispositional optimism on post-visit anxiety and risk perception accuracy among breast cancer 7 genetic counselees. Psycho-Oncology: 2013, 22(11), 2419-2427

TABLES AND FIGURES

Optimism within breast cancer genetic counselling

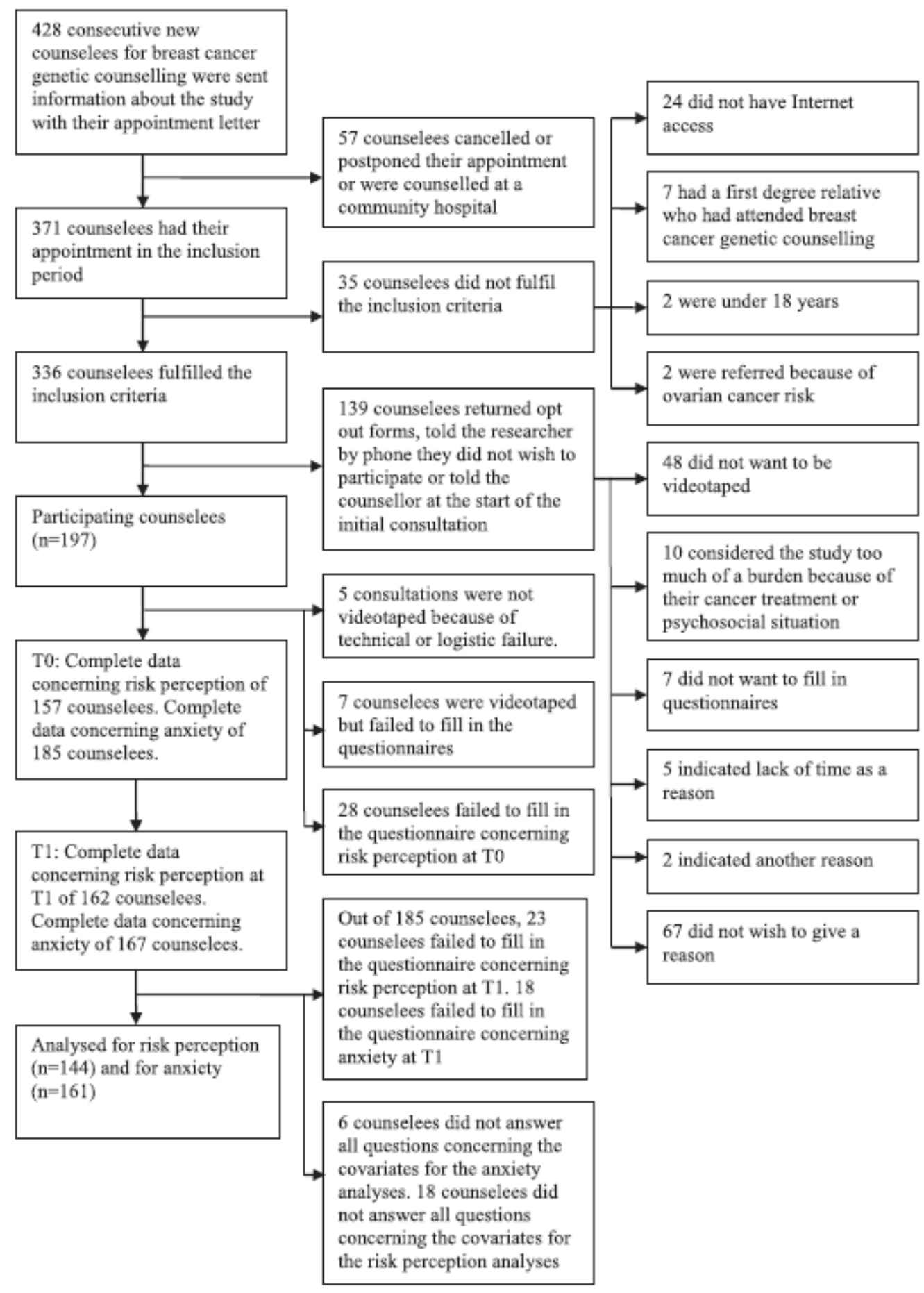

Figure I. Flow diagram 
Wiering, B.M., Albada, A., Bensing, J.M., Ausems, M.G.E.M., Dulmen, A.M. van. The influence of dispositional optimism on post-visit anxiety and risk perception accuracy among breast cancer 7 genetic counselees. Psycho-Oncology: 2013, 22(11), 2419-2427

Table I. Counselees' characteristics, $N=190$

\begin{tabular}{|c|c|c|}
\hline \multicolumn{3}{|l|}{ Counselees' characteristics } \\
\hline & $N$ & $\%$ \\
\hline Partner (having a partner) & 164 & 86.3 \\
\hline Children (having children) & 130 & 68.4 \\
\hline Personal history of breast cancer (affected) & 76 & 40.0 \\
\hline First-degree relatives affected with breast cancer & IOI & 53.2 \\
\hline \multicolumn{3}{|l|}{ Educational attainment } \\
\hline \multicolumn{3}{|l|}{ University (MSc/BSc)/ } \\
\hline Higher vocational education (BSC) & 78 & 41.1 \\
\hline Midde vocational education & 53 & 27.9 \\
\hline High school/secondary education & 55 & 29.0 \\
\hline$<$ High school level & 4 & 2.1 \\
\hline \multicolumn{3}{|l|}{ Referral pathway } \\
\hline GP & 91 & 48.7 \\
\hline Specialist consultant UMC & 49 & 26.2 \\
\hline Specialist consultant peripheral hospital & 47 & 25.1 \\
\hline \multicolumn{3}{|l|}{ Hereditary breast cancer risk* } \\
\hline Low $(\leq 10 \%$ risk) & 55 & 30.1 \\
\hline Moderate to high ( $>10 \%$ risk) & 128 & 70.0 \\
\hline \multirow[t]{2}{*}{ Indication for DNA testing** } & 144 & 75.8 \\
\hline & Range & Mean (SD) \\
\hline Optimism & $8.0-320$ & $2395(4.59)$ \\
\hline Arxiety (baseline) & $10.0-40.0$ & $1983(6.01)$ \\
\hline Arxicty (post-visit) & $10.0-40.0$ & $18.18(5.86)$ \\
\hline Acaracy of risk perception $* * *$ (baseline) & $1-100$ & $1903(2889)$ \\
\hline Acaracy of risk perception $* * *$ (post-visit) & $I-100$ & $500(2595)$ \\
\hline Age (years) & $21-69$ & $41.5(115)$ \\
\hline
\end{tabular}

Summations vary due to missing values. GP, General Practitioner; UMC, University Medical Centre; SD, standard deviation.

*Risk that breast cancer in the family is hereditary.

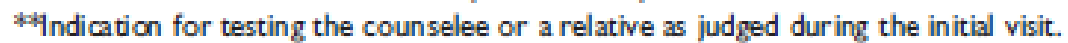

* Mean difference between counselee and counsellor's risk estimation. 
Wiering, B.M., Albada, A., Bensing, J.M., Ausems, M.G.E.M., Dulmen, A.M. van. The influence of dispositional optimism on post-visit anxiety and risk perception accuracy among breast cancer 7 genetic counselees. Psycho-Oncology: 2013, 22(11), 2419-2427

Table 2. Predictors and covariates of counselees' post-visit anxiety and the accuracy of risk perception

\begin{tabular}{|c|c|c|c|c|c|c|}
\hline \multirow[b]{2}{*}{ Predictors and covariates } & \multicolumn{3}{|c|}{ Post-visit anxiety $(N=161)$} & \multicolumn{3}{|c|}{$\begin{array}{l}\text { Post-visit accuracy of risk } \\
\text { perception }(N=144)\end{array}$} \\
\hline & $\beta$ & $95 \% \mathrm{Cl}$ & $p$ & $\beta$ & $95 \% \mathrm{Cl}$ & $p$ \\
\hline \multicolumn{7}{|l|}{ Model I } \\
\hline Anxiety (TO) & .50 & $.36-63$ &.$\infty$ & - & - & - \\
\hline Acaurate risk perception (TO) & - & - & - & .74 & $.60-88$ & .00 \\
\hline Risk estimation by counsellor & -.03 & $-.16-.09$ & .63 & - & - & - \\
\hline Optimism & -.27 & -.41 to -.13 & .0 & -.03 & $-.16-.09$ & 59 \\
\hline Breast cancer affected (yes' no) & .19 & $-.04-.43$ & .10 & .12 & $-.14-.38$ & .38 \\
\hline Indication for DNA testing & .06 & $-.24-37$ & .67 & .44 & $.15-.73$ & .00 \\
\hline Group allocation & .14 & $-.09-36$ & .23 & -.03 & $-.27-.20$ & .78 \\
\hline AIC & & 37752 & & & 33505 & \\
\hline \multicolumn{7}{|l|}{ Model 2} \\
\hline Anxiety (TO) & .46 & $.31-60$ &.$\infty$ & - & - & - \\
\hline Acaurate risk perception (TO) & - & - & - & .80 & $.67-93$ & .00 \\
\hline Risk estimation by counsellor & -.03 & $-.15-09$ & .63 & - & - & - \\
\hline Optimism & -.29 & -.43 to -.16 & .00 & -.04 & $-.15-.08$ & 56 \\
\hline Breast cancer affected (yes/no) & .20 & $-.04-43$ & .10 & .18 & $-.07-.43$ & .17 \\
\hline Indication for DNA testing & .05 & $-.25-.36$ & .72 & .40 & $.11-.68$ & .01 \\
\hline Group allocation & .12 & $-.10-34$ & .28 & -.07 & $-.30-.16$ & 54 \\
\hline No concerns expressed by the counselee (ref) & - & - & - & - & - & - \\
\hline One concem expressed & .16 & $-.24-56$ & .45 & -.15 & $-.56-.27$ & .49 \\
\hline More than one concern expressed & .26 & $-.02-53$ & .06 & -.05 & $-.32-.23$ & .74 \\
\hline No reassurance expressed by the counsellor (ref) & - & - & - & - & - & - \\
\hline One reassurance expressed & -.38 & $-.80-04$ & .08 & .11 & $-.33-.54$ & .63 \\
\hline More than one reassurances expressed & -.35 & -67 to -.04 & .03 & -.03 & $-.32-.27$ & .87 \\
\hline No empathy expressed by the counsellor (ref) & - & - & - & - & - & - \\
\hline Empathy was expressed once & -.14 & $-.84-56$ & .70 & .79 & $.06-1.52$ & .04 \\
\hline More than one expression of empathy & .13 & $-.47-.73$ & .67 & .92 & $.28-1.56$ & .01 \\
\hline Counsellors' eye gaze & -.02 & $-.14-.10$ & $\pi 7$ & -.12 & $-.24-.01$ & .06 \\
\hline AIC $-7-6-$ & & 37374 & & & 328.98 & \\
\hline
\end{tabular}

Analyses wer e contr olled for baseline values, disease status, group allocation and communication varia bles. For analyses concerning anxiety, the counsellor's risk estimation was controlled for. For anal yses concerning all counselees indication for DNA testing was also controlled for. TO, measured at baseline; TI, measured post-visit; AIC, Akaike information criterion.

Table 3. The categorization of counselees and counsellors' communication variables, $N=192$

\begin{tabular}{lcccc}
\hline Communication variables & Categories & Range & Frequency & Percentage \\
\hline Reassurance epressed by the coursellor & 0 & 0 & 40 & 20.8 \\
& 1 & 1 & 22 & 1.5 \\
Empatthy expressed by the counsellor & 2 & $2-28$ & 130 & 97.7 \\
& 0 & 1 & 9 & 4.7 \\
Concerns expressed by the counsellor & 1 & $2-49$ & 15 & 7.8 \\
& 2 & 1 & 67 & 87.5 \\
& 1 & $2-51$ & 19 & 34.9 \\
Duration of counsellors' eye gzze in percentages & 2 & & 106 & 9.9 \\
\hline
\end{tabular}

SD, standard deviation. 
Wiering, B.M., Albada, A., Bensing, J.M., Ausems, M.G.E.M., Dulmen, A.M. van. The influence of dispositional optimism on post-visit anxiety and risk perception accuracy among breast capcer genetic counselees. Psycho-Oncology: 2013, 22(11), 2419-2427

Table 4. The influence of counselees' baseline anxiety, optimism and risk perception on the counselees and counsellors' communication variables, $N=157$

\begin{tabular}{|c|c|c|c|c|c|c|c|c|c|}
\hline & \multicolumn{3}{|c|}{ Anxiety } & \multicolumn{3}{|c|}{ Optimism } & \multicolumn{3}{|c|}{ Risk perception } \\
\hline & $\boldsymbol{\beta}$ & $95 \% \mathrm{Cl}$ & $p$ & $\beta$ & $95 \% \mathrm{Cl}$ & $p$ & $\beta$ & $95 \% \mathrm{Cl}$ & $p$ \\
\hline Reassurance expressed by the counsellor & -.84 & -1.38 to -.29 &.$\infty$ & -.76 & $-|.3|$ to $-2 \mid$ & .01 & -.01 & $-.49-.46$ & .96 \\
\hline Empathy expressed by the counsellor & .78 & $-55-2.11$ & .25 & -.21 & $-1.70-1.29$ & .79 & -1.51 & -2.97 to -.06 & .04 \\
\hline Counsellors' eye gaze & .07 & $-.06-.21$ & .30 & .02 & $-.11-.16$ & .73 & -.03 & $-.17-.10$ & .61 \\
\hline Concerns expressed by the counselee & .08 & $-.32-.49$ & .69 & -.33 & $-.73-.08$ & .11 & -.08 & $-.46-.30$ & .67 \\
\hline
\end{tabular}

Analyses were controlled for disease status, indication for DNA testing risk as estimated by the counsellor and group allocation. For analyses concerning counsellors' communication, the expression of concerns by the counselee was controlled for. 